\title{
Identification of Physical, Morphological and Chemical Particularities of Mixed Microalgae - Bacteria Granules
}

\author{
COSTEL BUMBAC\#, ELENA MANEA\#, ALINA BANCIU, CATALINA STOICA, IOANA IONESCU, VALERIU BADESCU, \\ MIHAI NITA LAZAR* \\ National Research and Development Institute for Industrial Ecology - ECOIND, 71-73 Drumul Podu Dambovitei Str., 060652, \\ Bucharest, Romania
}

\begin{abstract}
The growth of population has been linked with the increase usage of chemical compounds design for domestic and industrial use. At its turn, the increased amount of the chemical compound puts an enhanced stress on the environment. In such scenario, the waste management, including the wastewater treatment strategies have become an important part for the environmental protection. Unfortunately, the wastewater treatment procedures have several components which could be improved. Among them aeration process and biomass sedimentation have been the most stringent to tackle, since the aeration alone consume more than $60 \%$ from wastewater treatment energy cost. In this study, we proposed a new microalgae-bacteria activated sludge granule which could be an economical and technological solution to the above mentioned issues such as aeration and sedimentation. Moreover, during this study we characterized the physical, morphological and chemical characteristic of the newly formed granules by advances techniques such as electronic and correlative microscopy.
\end{abstract}

Keywords: microalgae, bacteria, activated sludge

The global population growth induces a rise in industrialization, agriculture and use of more and more chemical compounds. Unfortunately, this increased production and consumption not only depletes the natural resources, but increases also the pollution stress on the environment. The wastewaters from domestic, industrial and agricultural processes had become an economical and environmental issue, triggering the need to develop economical efficient technologies for products recovered from wastewater. In order to tackle the environmental impact of wastewaters, more stringent requirements in terms of discharge quality have being adopted around the world while, operators are trying to update and upgrade the conventional wastewater treatment systems [1], based on physicochemical and microbiological treatment steps $[2,3]$ in different configurations and process conditions.

Conventional activated sludge treatment has evolved over the last 100 years in the urge to tackle the more stringent pollutants discharge regulations [4], evolving from configurations for organic matter removal only to combined solutions for organic matter and nitrogen removal and to enhanced biological phosphorus removal. The changes led to increased investment and operational costs. Enhanced biological nutrients removal based on conventional activated sludge requires the accommodation of different process conditions (anaerobic, anoxic and aerobic) or use of chemicals, leading to increased operational costs. For instance, aeration processes are energy-intensive, requiring $60-65 \%$ from total energy costs related to wastewater treatment [5]. Moreover, at a global scale, there are still problems regarding excess sludge management, mainly due to the continuous sludge production which imply high treatment costs necessary to meet the legislative restrictions for sludge disposal [6], which in turn could harm aquatic ecosystems stability and their ecological status [7 - 9]. Nowadays, in the recent circular economy context, researchers worldwide are trying to identify ways of turning wastewater from waste to resource able to generate marketable products. Recent trends in environmental biotechnology research are focusing away from conventional sludge processes development in the favour of newly developed, improved and intensive biological treatment solutions, one of which being mixed microalgae-bacteria granules technology.

Granular activated algae technology could be an interesting approach for treating wastewater and generating useful products such as biofuels with low cost and high efficiency [10,11], addressing the circular economy principles.

The key feature of granular-activated algae is the induced symbiosis among the bacteria and algae populations in the granular structures that enhances the quality of the treatment processes by leading to simultaneous removal of organic matter and nutrients (including nitrogen and phosphorus, the main drivers of eutrophication in water bodies), with reduced power requirements compared to conventional activated sludge systems due to the lack of aeration and sludge and mixed liquor return necessities.

This study analysis the production of the microalgaebacteria granules and brings new information about their physical, morphological and chemical particularities.

\section{Experimental part}

Microalgae-bacteria granules production

The laboratory installation consists of a sequencing batch bioreactor (Biostat $₫ A$ plus, Sartorius, Germany) and an external light source having a luminous flux of $3980 \mathrm{Im}$, light intensity at the exterior wall of the bioreactor being $215 \mu \mathrm{mol} / \mathrm{m}^{2} / \mathrm{s}$. The used volume of the bioreactor was $1 \mathrm{~L}, 0.5$ liter feeding volume, reaction time - $24 \mathrm{~h}$ and biomass settling time - $3 \mathrm{~min}$. The photoperiodicity was set for $15 \mathrm{~h}$ of light: $9 \mathrm{~h}$ of darkness for a period of $24 \mathrm{~h}$ of treatment. The rate of homogeneity of the reaction medium varied between $160 \mathrm{rpm}$ of $200 \mathrm{rpm}$. The purification process was carried out in the absence of aeration, the oxygen necessarry for the aerobic methabolism of bacteria 
being supplied exclusively by the photosynthesis process carried out by photoautotrophic microalgae in the light phase. The aim was to determine the efficiency of using the activated granular system in sewage treatment processes in sequential operation.

\section{Microscopy}

The activated algae granules were morphologically and structural analyzed by advanced techniques of electronic microscopy (Quanta 250 FEG Electronic Scanning Microscope) and stereo microscope (Leica M205 FA with PLO APO 2.0x PLAN and APO PLO 1.0x planes).

\section{Monitoring of the physical and chemical parameters}

$\mathrm{pH}$ and the dissolved oxygen saturation from the reaction medium $(0 \%)$ were continuously and automatically monitored by a Easy Ferm Plus K8 electrode 200 and OxyFerm FDA sensor 225 (Hamilton, Switzerland). The organic content was detected as chemical oxygen demand (CCOCr) ( $\mathrm{mg} \mathrm{O} / \mathrm{L}$ ) using the method described in the standard procedure SR ISO 6060-1996. The concentration of the cations $\left(\mathrm{NH}^{4+}, \mathrm{Ca}^{2+}, \mathrm{Mg}^{2+}\right)$ and the anions $\left(\mathrm{NO}_{2}\right.$, $\left.\mathrm{NO}_{3} ; \mathrm{PO}_{4}{ }^{3-}\right)(\mathrm{mg} / \mathrm{L})$ were detected using an ion chromatograph (ICS 3000 model DIONEX) based on SR EN ISO 14911-03, SR EN ISO 10304/1-09.

\section{Results and discussions}

The granules were tested in low-loaded wastewater that was obtained by diluting wastewater from the dairy processing industry. The diluted effluent had the following characteristics: $\mathrm{NH}_{4}^{+}(20.7-35 \mathrm{mg} / \mathrm{L}), \mathrm{NO}_{3}^{-}(<0.1 \mathrm{mg} / \mathrm{L})$, $\mathrm{PO}_{4}^{3-}\left(20-41 \mathrm{mg} / \mathrm{L}^{4}, \mathrm{Mg}^{2+}(23.8 \pm 3.2 \mathrm{mg} / \mathrm{L})\right.$ and $\mathrm{Ca}^{2+}$ $(25.5 \pm 4.3 \mathrm{mg} / \mathrm{L})$.

Biological samples (microalgae-bacteria granules) were periodically collected under well-defined conditions of bioreactor operation and then analyzed (table 1).

The results of the investigations conducted on wastewater with organic load (COD) between $<160$ and $550 \mathrm{mg} \mathrm{O} / \mathrm{L}$, carried out under sequential operation, demonstrated the viability of the granules in waste water treatment processes, these being materialized by removal efficiencies ranging between $60 \%$ and $99 \%$ for COD , 35\% and $71 \%$ for TKN, $20 \%$ and $70 \%$ for $\mathrm{NH}_{4}{ }^{+}$and $15 \%$ and $68 \%$ for PT (fig. 1).

The optimization of biological treatment processes was based on the results from the monitoring of chemical parameters (eg $\mathrm{NH}_{4}{ }^{+}, \mathrm{NO}_{2}$; dissolved oxygen, $\mathrm{pH}$ ) and physical parameters (feeding flow, temperature) in order to enhance process stability and increase the biological reactions' efficiency. However, sustained long-term performance can only be ensured when the microbial community in the activated algae granules works best.

Activated microalgae granules were characterized by a high sedimentation rate (reaching $18-31 \mathrm{~m} / \mathrm{h}$ at maturity) and ensured a 99\% microalgal cell recovery rate. In addition to the specific features already mentioned, the use of activated algae granules in wastewater treatment processes offeres other advantages such as aeration costs

\begin{tabular}{|c|c|c|c|c|c|}
\hline & $\mathrm{CCOCr}$ & $\mathrm{NH}_{4}^{+}$ & $\mathrm{PO}_{4}^{3-}$ & $\begin{array}{l}\text { Operational } \\
\text { parameters }\end{array}$ & Observations \\
\hline Sample & \multicolumn{3}{|c|}{ Loading rate $\left(\mathrm{g} / \mathrm{m}^{3} /\right.$ day $)$} & & \multirow{6}{*}{$\begin{array}{l}\text { TRH }=24 \mathrm{~h} ; \\
\text { photoperiodicity: } 15 \mathrm{~h} \text { light }+9 \mathrm{~h} \text { darkness; } \\
\text { output/input rates: } 50 \%\end{array}$} \\
\hline $\mathrm{X} 1^{*}$ & 80 & 6 & 3.3 & SBR & \\
\hline $\mathrm{X} 2^{*}$ & 80 & 6 & 3.3 & SBR & \\
\hline $\mathrm{X} 3^{*}$ & 80 & 6 & 3.3 & SBR & \\
\hline $\mathrm{X} 4^{*}$ & 80 & 6 & 3.3 & SBR & \\
\hline $\mathrm{X} 5^{*}$ & 80 & 6 & 3.3 & SBR & \\
\hline $\mathrm{X} 6^{*}$ & 270 & 12 & 20 & SBR & \multirow[t]{2}{*}{ Feeding the bioreactor, mixing at $200 \mathrm{rpm}$} \\
\hline $\mathrm{X} 7^{*}$ & 270 & 12 & 20 & SBR & \\
\hline
\end{tabular}

Table 1 THE OPERATIONAL CONDITIONS AT THE TIME OF SAMPLING

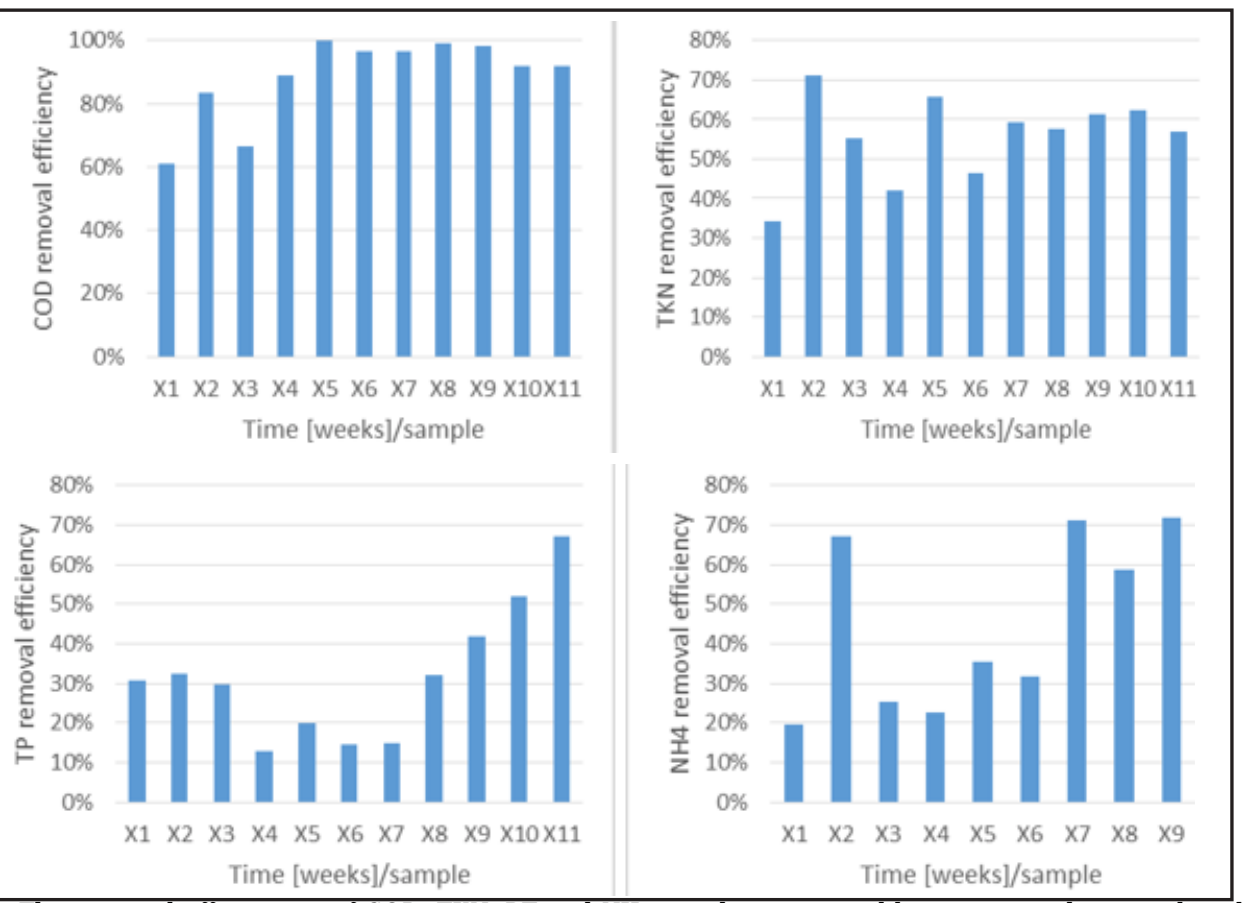

Fig. 1. The removal efficiencies of COD, TKN, PT and $\mathrm{NH}_{4}{ }^{+}$in the sequential bioreactor with microalgae-bacteria granules 

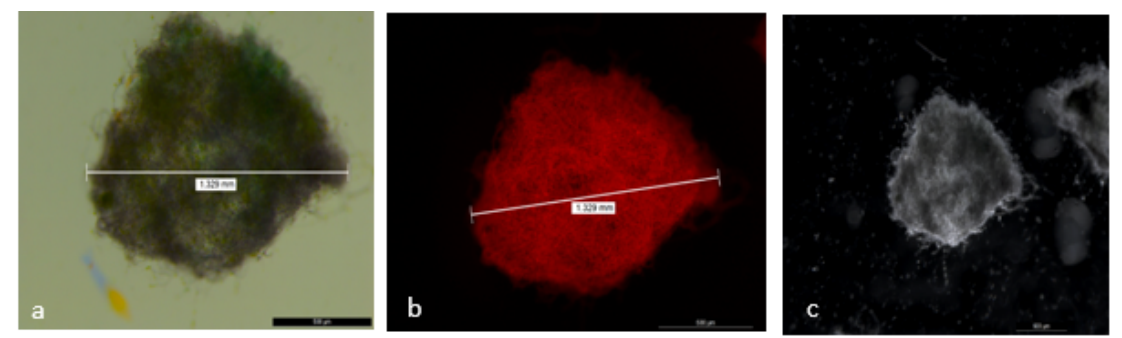

Fig. 2. a, Bright Field; b, Image fluorescence with GFP LP; c, Contrast image.

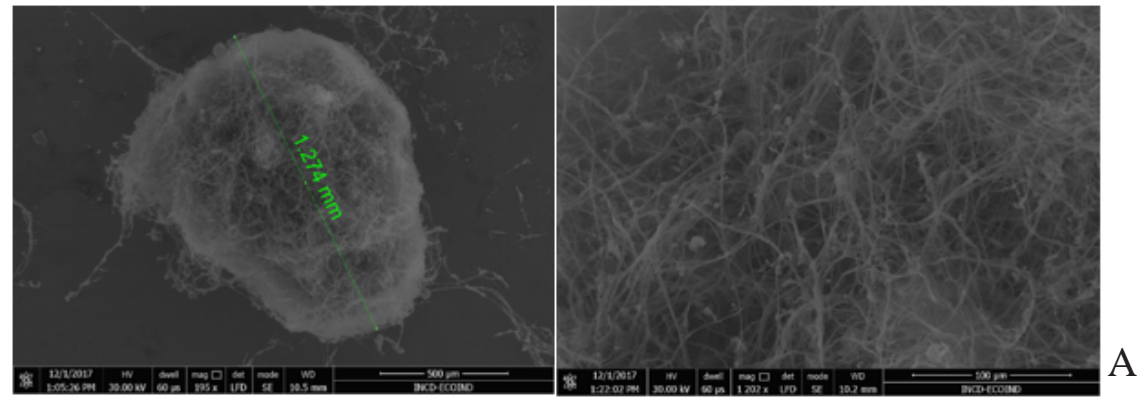

Fig. 3. Electron microscopy (SEM) analysis of granules from $A$ ) biological

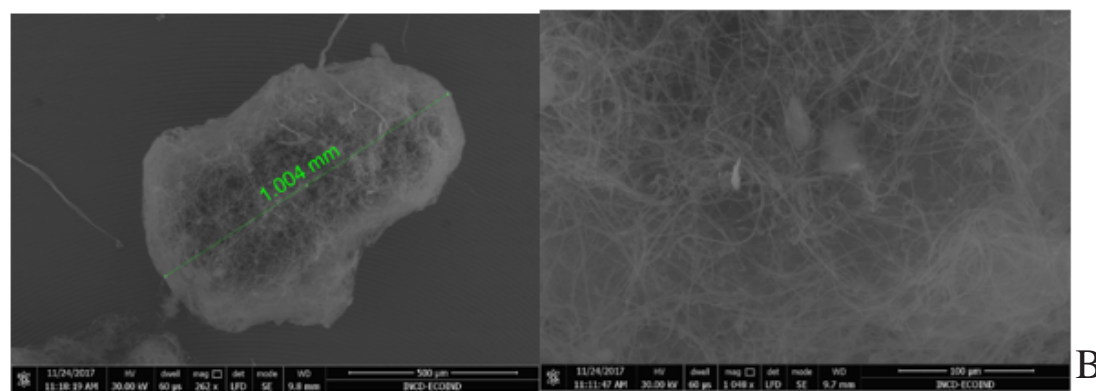

samples X1 - X5 and B) biological samples $\mathrm{X} 6-\mathrm{X} 7$

elimination, increase of waste recovery, reduction of greenhouse gas emissions.

Granules consisting of microalgal and bacterial taxa developed in symbiosis relationships and adapted to the characteristics of the considered wastewater [10]. From the category of microalgae were identified taxa of the genus Chlorella sp., Filamentous microalgae and diatoms. The approach of microalgae-bacterial granules analysis by two complementary microscopic techniques allowed analysis of some characteristics and their correlation with the operational parameters of the bioreactor.

The results demonstrated the existence of relatively similar granules in sizes between 1 and $3 \mathrm{~mm}$. Detailed analysis of microalgae-bacteria granule has revealed a homogeneous compaction degree (fig. 2).

Electron microscopy investigations were performed using the Quanta $250 \mathrm{FEG}$, FEl electronic scanning microscope. Different biological samples, microalgaebacteria granules, collected at different times were analyzed (fig. 3)

The results obtained at a magnification of $500 \mathrm{~mm}$ act and at $100 \mathrm{~mm}$ suggest a slight compaction of microalgabacteria mixed granules obtained by a bioreactor high rate versus those obtained from a rate of lower load (fig. 3).

\section{Conclusions}

The microalgae-bacteria symbiosis from the composition of the activated algae granules were very efficient in removing nutrients from wastewater. Moreover, they provide an easy collectable biomass which could be used as an energy source. The structural analysis of the microalgae granules showed a medium degree of compaction between microalgae and bacteria. The structure and the composition of the microalgae granules could change depending on the chemical characteristics of the influent wastewater. Using microalgae-bacteria granules in the biological stage of wastewater treatment plants could reduce the electrical energy demands by eliminating the need of external aeration in the activated sludge stage, which can represent more than 50 percent of the total energy of wastewater treatment plants.

Acknowledgements: This research was supported by grant PN-III-P4ID-PCE-2016-0865 from the Romanian National Authority for Scientific Research and Innovation CNCS/CCCDI-UEFISCDI. Authors thank to Sabrina Rosoiu for her inputs.

\section{References}

1. LI, W.W., YU, H.Q.Z. He, Energy Environ. Sci., 7, 2013, p. 911924.

2. NITA-LAZAR, M., GALAON, T., BANCIU, A., PAUN, I., STOICA, C., LUCACIU, I., J. Environ. Prot. Ecol., 17, no. 1, 2016, p. 237-247.

3.NITA-LAZAR, M., GHEORGHE, S., ANGHELACHE, A., BANCIU, A., STOICA, C., LUCACIU, I., Rev. Chim. (Bucharest), 67, no. 8, 2016, p. 1454-1457.

4. GHEORGHE, S., PETRE, J., LUCACIU, I., STOICA, C., NITA-LAZAR, M., Environ. Monit. Assess., 188, no. 6, 2016, p. 379.

5. DELRUE, F., ALVAREZ-DIAZ, P.D., FON-SING, S., FLEURY, G., SASSI, J.F., Energies, 9, no. 3, 2016, p. 132.

6. OLGUIN, E.J., Biotechnology Advances, 30, no. 5, 2012, p. 10311046.

7. STOICA, C., CAMEJ O, J., BANCIU, A., NITA-LAZAR, M., PAUN, I., CRISTOFOR, S., PACHECO, O.R., GUEVARA, M., Water Sci. Technol., 73, no.10, 2016, p. 2413-2421.

8. STOICA, C., GHEORGHE, S., PETRE, J., LUCACIU, I., NITA-LAZAR, M., Environ. Eng. Manag. J., 13, no. 9, 2014, p. 2243-2252.

9. STOICA, C., VASILE, G.G., BANCIU, A., LUCACIU, I., NITA LAZAR, M. Rev. Chim. (Bucharest), 68, no. 8, 2016, p. 1744-1748.

10. TIRON, O., BUMBAC, C., MANEA, E., STEFANESCU, M., NITALAZAR, M., Scientific Reports, 7, 4646, 2017, p.1-11.

11. GHEORGHE, S., VASILE, G.G., STOICA, C., NITA LAZAR M., LUCACIU, I., BANCIU, A. Rev. Chim. (Bucharest), 67, no. 8, 2016, p. 1469-1473.

Manuscript received: 12.08 .2018 